\title{
Layered/Layered Homostyructure Ion Conductor Coating Strategy for High Performance
}

\section{Lithium Ion Batteries}

\author{
Enyue Zhao ${ }^{\dagger}$, Minmin $\mathrm{Chen}^{\dagger}$, Zhongbo $\mathrm{Hu}^{\dagger}$, Xiaoling Xiao ${ }^{* \dagger}$ and Dongfeng Chen ${ }^{* *}$ \\ ${ }^{\dagger}$ College of Materials Science and Opto-electronic Technology University of Chinese Academy of Sciences, \\ Beijing 100049, P. R. China \\ $\$$ China Institute of Atomic Energy, Beijing 102413, P. R. China
}

*Corresponding Author: E-mail: xlxiao@ucas.ac.cn, Tel: +86 108825 6655; E-mail: dongfeng@ciae.ac.cn, Tel: +861069358015. 


\section{Abstract}

The $\mathrm{Li}_{2} \mathrm{MnO}_{3}$ coated $\mathrm{LiNi}_{0.8} \mathrm{Mn}_{0.1} \mathrm{Co}_{0.1} \mathrm{O}_{2}$ electrode has been sucessfully synthesized through a PVP-chelation and syn-lithiation strategy. X-ray diffraction (XRD) and X-ray photoelectron Spectrometer (XPS) characterizations are applied to verify the existence of the $\mathrm{Li}_{2} \mathrm{MnO}_{3}$ surface layer. The complete and nanoscale $\mathrm{Li}_{2} \mathrm{MnO}_{3}$ coating layer strongly adheres to the host material because of the layered/layered homostyructure, improves the content of Mn element on the surface of the electrode and has three-dimensional path for $\mathrm{Li}^{+}$-ion diffusion. Due to the numerous unique and dramatic advantages of the $\mathrm{Li}_{2} \mathrm{MnO}_{3}$ surface layer, the layered/layered homostyructure electrode exhibits superior cycle stability, rate capability and other electrochemical properties. The newly developmental coating material and versatile nanocoating strategy can also be popularized and applied in other electrode materials.

Keywords: Layered cathode materials; $\mathrm{Li}_{2} \mathrm{MnO}_{3}$-coated; Lithium-ion conductor; synchronous lithiation strategy 


\section{Introduction}

Layered lithium-mixed transition metal oxides, $\mathrm{LiMO}_{2}(\mathrm{M}=\mathrm{Ni}, \mathrm{Co}, \mathrm{Mn})$ have appeared to be candidates as cathode materials for lithium-ion batteries, due to their unique advantages such as high energy density, good thermal stability, low cost, and low toxicity [1-6]. However, there are still some drawbacks for layered $\mathrm{LiMO}_{2}$ materials to prevent their sustainable and high-power applications. For example, the intrinsic lower $\mathrm{Li}^{+}$-ion conductivity of layered $\mathrm{LiMO}_{2}$ materials result in inferior rate performance for lithium-ion batteries [7-10]. The highly reactive $\mathrm{Ni}^{4+}$ or $\mathrm{Co}^{4+}$ are unstable in organic electrolyte, which could lead to capacity fading and produce a series of safety issues $[7,11]$.

Based on these existing challenges for $\mathrm{LiMO}_{2}$ materials, surface modification has been used as an effective strategy to improve their electrochemical properties [12-18]. At present, the mainly coating materials are electrochemically inert oxides and phosphates such as $\mathrm{ZrO}_{2}, \mathrm{Al}_{2} \mathrm{O}_{3}$ et al $[14,18]$. Unfortunately, these coating materials are ion insulator, which are not favorable for both $\mathrm{Li}^{+}$-ion conduction of cathode materials and interfacial charge transfer of the electrode [19]. A class of coating materials of ion conductor, such as $\mathrm{Li}_{2} \mathrm{TiO}_{3}, \mathrm{Li}_{2} \mathrm{ZrO}_{3}$ and $\mathrm{Li}_{2} \mathrm{SiO}_{3}$, can avoid the aforesaid drawbacks because of their unique structure. These coating materials can not only act as a protective layer to stabilize the surface structure of cathode materials, suppress metal-ion dissolution and unfavorable interfacial side reactions, but also have three-dimensional path for $\mathrm{Li}^{+}$-ion diffusion which can effectively increase $\mathrm{Li}^{+}$-ion conduction [20-26]. For example, we have demonstrated the availability of the $\mathrm{Li}_{2} \mathrm{SiO}_{3}$ coating material in ameliorating the electrochemical performance of layered cathode materials [25, 26].

Monoclinic $\mathrm{Li}_{2} \mathrm{MnO}_{3}$, similar to aforementioned ion conductor coating materials, also has three-dimensional path for $\mathrm{Li}^{+}$-ion diffusion [27]. (Figure 1b). More importantly, $\mathrm{Li}_{2} \mathrm{MnO}_{3}$ 
possesses some unique advantages in comparison to other coating materials. Firstly, the layered $\mathrm{Li}_{2} \mathrm{MnO}_{3}$ has the interlamellar (002) d-spacing value of $0.480 \mathrm{~nm}$ which can match well with $(003)$ d-spacing of $\mathrm{LiMO}_{2}(0.468 \mathrm{~nm})$. The simultaneous existence of the two phases of $\mathrm{Li}_{2} \mathrm{MnO}_{3}$ and $\mathrm{LiMO}_{2}$ in lithium-rich materials further proved the $\mathrm{Li}_{2} \mathrm{MnO}_{3}$ material, as a surface layer, could bond well with $\mathrm{LiMO}_{2}$ materials [28,29]. Furthermore, the homostyructure and similar interlamellar d-spacing is favorable for the formation of the $\mathrm{Li}_{2} \mathrm{MnO}_{3}$ surface layer with ideal crystal structure, which can better preserve the three-dimensional ionic channels. Secondly, the $\mathrm{Li}_{2} \mathrm{MnO}_{3}$ coating layer can increase the content of Mn element on the surface of the layered $\mathrm{LiMO}_{2}$ materials, forming a concentration-gradient structure which is advantageous for the improvement of the cycle stability and safety performance [5,30-32]. In this study, we selected $\mathrm{Li}_{2} \mathrm{MnO}_{3}$, which possesses numerous dramatic advantages compared with other coating materials, as the coating layer to improve the electrochemical performances of $\mathrm{LiNi}_{0.8} \mathrm{Mn}_{0.1} \mathrm{Co}_{0.1} \mathrm{O}_{2}$.

As to the coating strategy, It is difficult to establish a uniform, complete and controllable coating layer on the host materials through conventional approaches such as mechanical mixing and so on [33-35]. It has been reported that metal ions tend to entangle onto the backbone of the poly(vinyl pyrrolidone) (PVP) and its long polymeric chain structure will surround the samples [36-38]. Therefore, in our coating strategy, the $\mathrm{Ni}_{0.8} \mathrm{Mn}_{0.1} \mathrm{Co}_{0.1} \mathrm{O}_{2}(\mathrm{OH})_{2}$ precursor was first coated with the PVP, then the dissolved $\mathrm{Mn}^{2+}$ ions were complexed with the entire PVP backbone previously coated on the hydroxide precursors. In this way, the $\mathrm{Mn}^{2+}$ ions can uniformly distribute on the surface of the hydroxide precusor. Finally, a syn-lithiation method was adopted to get the $\mathrm{Li}_{2} \mathrm{MnO}_{3}$ coated $\mathrm{LiNi}_{0.8} \mathrm{Mn}_{0.1} \mathrm{Co}_{0.1} \mathrm{O}_{2}$. (Figure 1a) Our studies show that the electrochemical properties of layered $\mathrm{LiNi}_{0.8} \mathrm{Mn}_{0.1} \mathrm{Co}_{0.1} \mathrm{O}_{2}$ materials have been significantly enhanced by coating a 
layer of $\mathrm{Li}_{2} \mathrm{MnO}_{3}$.

\section{Experimental section}

\subsection{Materials preparation}

Firstly, the hydroxide precusor $\left(\mathrm{Ni}_{0.8} \mathrm{Mn}_{0.1} \mathrm{Co}_{0.1}(\mathrm{OH})_{2}\right)$ was prepared by a co-precipitation (CP) method. Stoichiometric amounts of nickel sulfate, manganese sulfate and cobalt sulfate were dissolved in deionized water. The $\mathrm{NaOH}$ solution was added into the above solution under violently stirring. The obtained hydroxide precusor was then filtered, washed, and dried at $80{ }^{\circ} \mathrm{C}$ overnight. Secondly, $10 \mathrm{mmol}$ of the $\mathrm{Ni}_{0.8} \mathrm{Mn}_{0.1} \mathrm{Co}_{0.1}(\mathrm{OH})_{2}$ precursor was mixed with $1 \mathrm{mmol}$ of $\mathrm{Mn}\left(\mathrm{CH}_{3} \mathrm{COO}\right)_{2} \cdot 4 \mathrm{H}_{2} \mathrm{O}$ in deionized water, in which $0.3 \mathrm{~g}$ of poly(vinyl pyrrolidone) (PVP) had been previously dissolved at $50{ }^{\circ} \mathrm{C}$ for $12 \mathrm{~h}$. The mixed solution was then dried at $80{ }^{\circ} \mathrm{C}$ overnight. Finally, the PVP-Mn-coated hydroxide precusor was mixed with stoichiometric amounts of LiOH. One part amounts of $\mathrm{LiOH}$ was used to lithiate the hydroxide precursor to form $\mathrm{LiMO}_{2}$, the other part was used to lithiate the manganese acetate to form $\mathrm{Li}_{2} \mathrm{MnO}_{3}$. The mixtures were then calcinated in the air atmosphere at $800{ }^{\circ} \mathrm{C}$ for 12 hours with a heat rate of $5{ }^{\circ} \mathrm{C} \cdot \mathrm{min}^{-1}$ to get the $\mathrm{Li}_{2} \mathrm{MnO}_{3}$ coated $\mathrm{LiNi}_{0.8} \mathrm{Mn}_{0.1} \mathrm{Co}_{0.1} \mathrm{O}_{2}$. During this syn-lithiation process, the hydroxide precusor $\mathrm{Ni}_{0.8} \mathrm{Mn}_{0.1} \mathrm{Co}_{0.1}(\mathrm{OH})_{2}$ was lithiated to $\mathrm{LiNi}_{0.8} \mathrm{Mn}_{0.1} \mathrm{Co}_{0.1} \mathrm{O}_{2}$, simultaneously the outer manganese acetate was lithiated to $\mathrm{Li}_{2} \mathrm{MnO}_{3}$. The pristine $\mathrm{LiNi}_{0.8} \mathrm{Mn}_{0.1} \mathrm{Co}_{0.1} \mathrm{O}_{2}$ was prepared using the same synthesis process without addition of $\mathrm{Mn}\left(\mathrm{CH}_{3} \mathrm{COO}\right)_{2} \cdot 4 \mathrm{H}_{2} \mathrm{O}$.

\subsection{Materials characterization}

Powder X-ray diffraction (XRD) was performed on Rigaku Ultima IV-185 with $\mathrm{Cu} \mathrm{K} \alpha$ radiation between 10 and $80^{\circ} 2 \theta$ at a scan rate of $1^{\circ} 2 \theta \mathrm{min}^{-1}$. Elemental analysis measurements were carried out on a SPECTRO ARCOS FHS12 ICP-OES Spectrometer. Particle morphologies 
of the prepared powders were observed by scanning electron microscope (SEM, Hitachi S4800) and transmission electron microscopy (TEM, FEI Tecnai G2 F20). XPS spectra was obtained using a Kratos Axis ULTRA X-ray photoelectron Spectrometer under UHV conditions.

\subsection{Electrochemical Measurement}

For prepartion of the positive electrode, $80 \mathrm{wt} \%$ active material, $10 \mathrm{wt} \%$ carbon black, and 10 wt\% polyvinylidene fluoride (PVDF) were grinded to slurry with N-methylpyrrolidinon, and then spread on aluminum foil with doctor blade. The electrodes were dried overnight at $120{ }^{\circ} \mathrm{C}$ in a vacuum oven. The loading density of the active material is about $3-4 \mathrm{mg} / \mathrm{cm}^{2}$. The 2016-type coin cells were assembled in an Ar-filled glove box using Li foil as the counter electrode. The electrolyte was $1 \mathrm{~mol} / \mathrm{L} \mathrm{LiPF}_{6}$ in a $1: 1$ mixture of ethylene carbonate (EC)/dimethyl carbonate (DMC) and the separator was Celgard 2500. Galvanostatic charge-discharge cycling was tested between 3.0-4.3V (vs. $\mathrm{Li}^{-\mathrm{Li}^{+}}$) using automatic galvanostat (NEWARE). PITT tests were carried out on the Metrohm-Autolab (PGSTAT 302N). All electrochemical measurements were performed at $25^{\circ} \mathrm{C}$.

\section{Results and discussion}

Figure 2 shows the X-ray photoelectron spectroscopy (XPS) results of the hydroxyl precursor $\mathrm{Ni}_{0.8} \mathrm{Mn}_{0.1} \mathrm{Co}_{0.1}(\mathrm{OH})_{2}$, It can be seen that the valences of $\mathrm{Ni}, \mathrm{Mn}$ and Co in reactants were all $2+$ [39]. Although it has been reported that the $\mathrm{Mn}^{2+}$ in the $\mathrm{Mn}(\mathrm{OH})_{2}$ is easily oxidized to $\mathrm{Mn}^{4+}$ in the aqueous solution, which lead to the appearance of $\mathrm{Mn}_{2} \mathrm{O}_{3}$ or $\mathrm{MnO}_{2}$ in the precursor, the content of the $\mathrm{Mn}^{4+}$ in the precursor is relatively less which would not influence the average valence of $\mathrm{Mn}$ element [40]. Figure 3a exhibits the powder XRD patterns of the pristine $\mathrm{LiNi}_{0.8} \mathrm{Mn}_{0.1} \mathrm{Co}_{0.1} \mathrm{O}_{2}$ and the $\mathrm{Li}_{2} \mathrm{MnO}_{3}$ coated $\mathrm{LiNi}_{0.8} \mathrm{Mn}_{0.1} \mathrm{Co}_{0.1} \mathrm{O}_{2}$ materials. Both materials show hexagonal system and a 
signal phase of well-defined $\alpha-\mathrm{NaFeO}_{2}$ structure (space group: R3-m). The splitting of paired diffraction peaks $(018) /(110)$ and $(006) /(102)$ are known to be an indicator of well layered structure [8,9]. It's worth noting that no peaks corresponding to monoclinic $\mathrm{Li}_{2} \mathrm{MnO}_{3}$ can be found, which may be due to the lower loading content. The characteristic peaks for monoclinic $\mathrm{Li}_{2} \mathrm{MnO}_{3}$ between $20-22^{\circ}$ began to appear with the content of $\mathrm{Mn}: \mathrm{M}(\mathrm{OH})_{2}$ increasing to 50:100 (Figure 3b). This result may prove that the $\mathrm{Li}_{2} \mathrm{MnO}_{3}$ was formed during the calcination with stoichiometric $\mathrm{Li}$ salt, though it was not detected by XRD while the content of $\mathrm{Mn}: \mathrm{M}(\mathrm{OH})_{2}$ is 10:100. In addition, the elemental analysis results show that the actual content of the elements is in good agreement with the theoretical content in the pristine and $\mathrm{Li}_{2} \mathrm{MnO}_{3}$ coated materials. (Table 1)

The scanning electron microscopy (SEM) pictures of pristine and $\mathrm{Li}_{2} \mathrm{MnO}_{3}$ coated samples in various magnifications are shown in Figure 4. All the particles are well-crystallized which is consistent with the results of the sharp peaks in the X-ray diffraction (XRD) patterns. It can be seen that there is almost no difference between the pristine and $\mathrm{Li}_{2} \mathrm{MnO}_{3}$ coated materials, and morphologies of both materials are irregular cake, the average particle size of the particles is about $300-500 \mathrm{~nm}$.

Figure 5a shows the transmission-electron-microscopy (TEM) image of the $\mathrm{Li}_{2} \mathrm{MnO}_{3}$ coated $\mathrm{LiNi}_{0.8} \mathrm{Mn}_{0.1} \mathrm{Co}_{0.1} \mathrm{O}_{2}$ sample. It can be seen that there is a clear coating layer on the surface of the host material. The thickness of the coating layer is very uniform, and which is about $5 \mathrm{~nm}$. A high-resolution TEM (HRTEM) image of the $\mathrm{Li}_{2} \mathrm{MnO}_{3}$ coated sample in the inset in Figure 5a reveals that the inner material and the external coating layer have lattice spacings of 0.47 and 0.43 $\mathrm{nm}$, which can be indexed to the (003) plane of $\mathrm{LiNi}_{0.8} \mathrm{Mn}_{0.1} \mathrm{Co}_{0.1} \mathrm{O}_{2}$ and the (020) plane of $\mathrm{Li}_{2} \mathrm{MnO}_{3}$, respectively $[7,41,42]$. The results of elemental mapping for $\mathrm{Ni}, \mathrm{Mn}$ and $\mathrm{Co}$ in Figure 
$5 \mathrm{c}-\mathrm{e}$ indicate that the transition metal elements uniformly distribute in the $\mathrm{Li}_{2} \mathrm{MnO}_{3}$ coated $\mathrm{LiNi}_{0.8} \mathrm{Mn}_{0.1} \mathrm{Co}_{0.1} \mathrm{O}_{2}$ sample, and can not indicate that there is a clear $\mathrm{Li}_{2} \mathrm{MnO}_{3}$ coating layer on the surface of the $\mathrm{Li}_{2} \mathrm{MnO}_{3}$ coated $\mathrm{LiNi}_{0.8} \mathrm{Mn}_{0.1} \mathrm{Co}_{0.1} \mathrm{O}_{2}$ material, which may be due to the ultrathin thickness of the coating layer.

In the similar circumstances, convergent beam electron diffraction and $\mathrm{Li}^{7}$ MAS NMR have been reported to study the complexity of structure of the (1-x) $\mathrm{LiMO}_{2} \cdot \mathrm{xLi}_{2} \mathrm{MnO}_{3}$ [34]. Nevertheless, these methods are not suited for the characterization of the coating layer on nanostructures. Instead, X-ray photoelectron spectroscopy (XPS), which only collects photoelectrons from atoms neighboring to the interface within $8-10 \mathrm{~nm}$, has been applied to determine the surface content of elements [39,43]. Figure 5f-h show the result of XPS characterization for the $\mathrm{Li}_{2} \mathrm{MnO}_{3}$ coated sample. It can be determined that the valences of $\mathrm{Ni}, \mathrm{Mn}$ and Co are 2+, 4+ and 3+, respectively [39]. In addition, it should be noted that the atomic ratio of $\mathrm{Mn}:(\mathrm{Ni}+\mathrm{Co})$ determined by XPS is much bigger compared with the original feed ratio in the precursor during synthetic process. (Table 2) The phenomenon again demonstrates that there is a $\mathrm{Li}_{2} \mathrm{MnO}_{3}$-rich coating layer on the surface of the layered $\mathrm{LiNi}_{0.8} \mathrm{Mn}_{0.1} \mathrm{Co}_{0.1} \mathrm{O}_{2}$. In addition, it can be speculated that there is a lithium-rich $\mathrm{xLi}_{2} \mathrm{MnO}_{3} \cdot(1-\mathrm{x}) \mathrm{LiMO}_{2}$ transitional phase between the host material $\mathrm{LiMO}_{2}$ and $\mathrm{Li}_{2} \mathrm{MnO}_{3}$ surface coating layer. (Figure 1c) The unique structure could produce a strong interaction between $\mathrm{Li}_{2} \mathrm{MnO}_{3}$ and the host material, which can effectively restrain the shedding of $\mathrm{Li}_{2} \mathrm{MnO}_{3}$ coating layer during the long cycle.

In order to investigate the influence of the $\mathrm{Li}_{2} \mathrm{MnO}_{3}$ coating layer on the electrochemical properties of $\mathrm{LiNi}_{0.8} \mathrm{Mn}_{0.1} \mathrm{Co}_{0.1} \mathrm{O}_{2}$. Pristine and $\mathrm{Li}_{2} \mathrm{MnO}_{3}$ coated $\mathrm{LiNi}_{0.8} \mathrm{Mn}_{0.1} \mathrm{Co}_{0.1} \mathrm{O}_{2}$ cells were charged/discharged galvanostatically between 3.0 and $4.3 \mathrm{~V}$ at $25^{\circ} \mathrm{C}$. Figure $6 \mathrm{a}$ shows the cycling 
performances of the pristine and $\mathrm{Li}_{2} \mathrm{MnO}_{3}$ coated electrodes at the rate of $1 \mathrm{C}(160 \mathrm{~mA} / \mathrm{g})$. It is clear that the $\mathrm{Li}_{2} \mathrm{MnO}_{3}$ coated electrode exhibits higher discharge capacity than that of the pristine $\mathrm{LiNi}_{0.8} \mathrm{Mn}_{0.1} \mathrm{Co}_{0.1} \mathrm{O}_{2}$ material during the whole cycle process. To be specific, the $\mathrm{Li}_{2} \mathrm{MnO}_{3}$ coated electrode delivered approximately a discharge capacity of $109 \mathrm{mAh} / \mathrm{g}$ which increased by $47 \%$ compared with that of $74 \mathrm{mAh} / \mathrm{g}$ for the pristine sample. The improved specific capacity can be ascribed to the nanoscale $\mathrm{Li}_{2} \mathrm{MnO}_{3}$ coating layer, which dramatically improves the lithium ions diffusion coefficient. Furthermore, the $\mathrm{Li}_{2} \mathrm{MnO}_{3}$ modified electrode also shows distinct advantage in cycle stability. The capacity retention of the pristine and $\mathrm{Li}_{2} \mathrm{MnO}_{3}$ coated $\mathrm{LiNi}_{0.8} \mathrm{Mn}_{0.1} \mathrm{Co}_{0.1} \mathrm{O}_{2}$ electrodes are $69 \%$ and $83 \%$, respectively, after 150 cycles. The ameliorative cycle stability of the $\mathrm{Li}_{2} \mathrm{MnO}_{3}$ coated sample can be ascribed to the reasons that the $\mathrm{Li}_{2} \mathrm{MnO}_{3}$ coating layer effectively inhibits the decomposition of the electrolyte, reduces the unfavorable interfacial side reactions. Moreover, the $\mathrm{Li}_{2} \mathrm{MnO}_{3}$ coating layer improves the content of Mn element on the surface of the sample, which could stabilize the structure of the electrode and thus improve the cycle stability [5,30-32].

Further differences of electrochemical performances between the pristine and $\mathrm{Li}_{2} \mathrm{MnO}_{3}$ modified materials are shown in Figure 6b. It can be clearly observed that the gap between the charge and discharge plateau regions for the $\mathrm{Li}_{2} \mathrm{MnO}_{3}$ coated electrode is much smaller after 150 cycles than that for the pristine electrode, which indicates that the $\mathrm{LiNi}_{0.8} \mathrm{Mn}_{0.1} \mathrm{Co}_{0.1} \mathrm{O}_{2}$ material modified by $\mathrm{Li}_{2} \mathrm{MnO}_{3}$ has lower polarization. It has been demonstrated that the $\mathrm{Li}_{2} \mathrm{MnO}_{3}$ coating layer has preferable crystal structure, which means that the three-dimensional path for $\mathrm{Li}^{+}$-ion diffusion could fully exist. The diffusion rate of lithium ions for the $\mathrm{Li}_{2} \mathrm{MnO}_{3}$ coated electrode can be highly enhanced, and thus reduce its electrode polarization. 
Figure $6 \mathrm{c}$ and $\mathrm{d}$ display the $\mathrm{dQ} / \mathrm{dV}$ plots of pristine and $\mathrm{Li}_{2} \mathrm{MnO}_{3}$ coated electrodes, respectively, which are calculated from numerical data observed in discharge profiles of various cycles. During cycle process, the reduction peaks of the pristine electrode shift continuously toward lower potential, whereas the reduction peaks of the $\mathrm{Li}_{2} \mathrm{MnO}_{3}$ coated electrode are almost overlapping. It is well known that the shift of reduction peaks represents the voltage decline to some extent [44]. More direct results can be found in the insets of Figure $6 \mathrm{c}$ and d, the discharge voltage plateau of the pristine and $\mathrm{Li}_{2} \mathrm{MnO}_{3}$ coated electrodes decreased by $2.6 \%$ and $0.5 \%$, respectively. It can be concluded that the existence of $\mathrm{Li}_{2} \mathrm{MnO}_{3}$ on the surface of the $\mathrm{LiNi}_{0.8} \mathrm{Mn}_{0.1} \mathrm{Co}_{0.1} \mathrm{O}_{2}$ electrode alleviates its voltage drop.

The good rate capability of $\mathrm{Li}_{2} \mathrm{MnO}_{3}$ coated electrode further demonstrated the advantages of the $\mathrm{Li}^{+}$-conductive $\mathrm{Li}_{2} \mathrm{MnO}_{3}$ coating layer (Figure 6e). Both pristine and $\mathrm{Li}_{2} \mathrm{MnO}_{3}$ coated materials were characterized at the rate of $0.2 \mathrm{C}-5.0 \mathrm{C}$ during 3.0-4.3 V with 5 cycles per step. As shown in Figure 6e, the $\mathrm{Li}_{2} \mathrm{MnO}_{3}$ coated sample shows high rate capability, while the pristine sample tested for comparison exhibits a poor rate capability, a dramatic capacity drop with the increasing of C-rate. At the rate of $5.0 \mathrm{C}$, the $\mathrm{Li}_{2} \mathrm{MnO}_{3}$ coated material delivered a discharge capacity of $48 \mathrm{mAh} / \mathrm{g}$, which increased by $140 \%$ compared with the $20 \mathrm{mAh} / \mathrm{g}$ of the pristine $\mathrm{LiNi}_{0.8} \mathrm{Mn}_{0.1} \mathrm{Co}_{0.1} \mathrm{O}_{2}$ electrode. The enhanced rate capability is due to the high $\mathrm{Li}^{+}$conductive coating layer on the surface of the electrode which made the $\mathrm{Li}_{2} \mathrm{MnO}_{3}$ coated material has good $\mathrm{Li}^{+}$inserting/extracting kinetics.

To better figure out the reasons why the $\mathrm{Li}_{2} \mathrm{MnO}_{3}$ coated electrode presented more superior electrochemical performances than the pristine sample, a potentiostatic intermittent titration technique (PITT) test was performed. Before measurement, the cells were galvanostatically 
charged and discharged in one cycle at the rate of $1 \mathrm{C}$ between 3.0 and $4.3 \mathrm{~V}$ at $25^{\circ} \mathrm{C}$. The lithium ions diffusion coefficient ( $\mathrm{D}_{\mathrm{Li}}$, an important kinetic parameter of intercalation materials) can be obtained by the following equation:

$D_{L i}=-\frac{d \ln (Q)}{d t}-\frac{4 L^{2}}{\pi^{2}}$

in which $\mathrm{L}$ is the thickness of the electrode active material on the aluminum foil $[45,46]$. The PITT curves of the pristine and $\mathrm{Li}_{2} \mathrm{MnO}_{3}$ coated $\mathrm{LiNi}_{0.8} \mathrm{Mn}_{0.1} \mathrm{Co}_{0.1} \mathrm{O}_{2}$ electrodes as a function of time between 3.0 and $4.3 \mathrm{~V}$ are shown in Figure $7 \mathrm{a}$ and b, respectively. On the basis of the PITT measurement and corresponding data calculation, the results of $\mathrm{D}_{\mathrm{Li}}$ as a function of the charge-discharge voltage can be obtained (Figure $7 \mathrm{c}$ and d). During both the charge and discharge processes, the $\mathrm{Li}_{2} \mathrm{MnO}_{3}$ coated electrode exhibits higher $\mathrm{D}_{\mathrm{Li}}$ than that of the pristine electrode. In addition, a physical protection layer could not cause the change of $\mathrm{D}_{\mathrm{Li}}$ [47]. Therefore, the PITT results not only give a convincing explanation for the superior electrochemical performance of the coated cathode material, but also demonstrate the surface phase is epitaxially connected to the host material without any defect.

\section{Conclusions}

In summary, the $\mathrm{Li}_{2} \mathrm{MnO}_{3}$ coated $\mathrm{LiNi}_{0.8} \mathrm{Mn}_{0.1} \mathrm{Co}_{0.1} \mathrm{O}_{2}$ electrode has been sucessfully prepared via a PVP-chelation and syn-lithiation strategy. XPS characterization was applied to demonstrate the existence of the $\mathrm{Li}_{2} \mathrm{MnO}_{3}$ surface layer. The nanoscale coating layer is confirmed to be responsible for the high capacity, excellent cycling stability, outstanding rate capability, and relieved voltage decay. It is found that (1) the inert and relative uniform $\mathrm{Li}_{2} \mathrm{MnO}_{3}$ surface layer suppresses the electrochemical side reactions at high voltage; (2) the homostyructure and similar interlamellar d-spacing strengthens the bonding between the coating layer and the host material; (3) 
perfect crystal structure of $\mathrm{Li}_{2} \mathrm{MnO}_{3}$ surface layer produces the preferably existence of 3D path for $\mathrm{Li}^{+}$-ion diffusion and (4) the increased content of $\mathrm{Mn}^{4+}$ on the surface is favorable for the structural stability of the electrode material. The newly developmental coating material and versatile nanocoating strategy adopted in this work should inspire the development of other advanced electrode materials with excellent performances for lithium-ion batteries.

\section{Acknowledgements}

This work was supported by the Beijing Nova Program (Z141103001814065), the Youth Innovation Promotion Association CAS (2016152), National Science Foundation for Young Scholars of China (21201177), the State Key Project of Fundamental Research (2014CB931900 and 2012CB932504).

\section{References}

[1] F. Lin, I.M. Markus, D. Nordlund, T.-C. Weng, M.D. Asta, H.L. Xin, M.M. Doeff, Surface reconstruction and chemical evolution of stoichiometric layered cathode materials for lithium-ion batteries, Nat. Commun. 5 (2014) 3529.

[2] H. Yu, Y. Qian, M. Otani, D. Tang, S. Guo, Y. Zhu, H. Zhou, Study of the lithium/nickel ions exchange in the layered $\mathrm{LiNi}_{0.42} \mathrm{Mn}_{0.42} \mathrm{Co}_{0.16} \mathrm{O}_{2}$ cathode material for lithium ion batteries: experimental and first-principles calculations, Energy Environ. Sci. 7 (2014) 1068-1078.

[3] J.B. Goodenough, Y. Kim, Challenges for Rechargeable Li Batteries, Chem. Mater. 22 (2010) $587-603$.

[4] J. Wang, C. Du, C. Yan, X. He, B. Song, G. Yin, P. Zuo, X. Cheng, $\mathrm{Al}_{2} \mathrm{O}_{3}$ Coated Concentration-Gradient $\mathrm{LiNi}_{0.73} \mathrm{Co}_{0.12} \mathrm{Mn}_{0.15} \mathrm{O}_{2}$ Cathode Material by Freeze Drying for Long-Life Lithium Ion Batteries, Electrochim. Acta 174 (2015) 1185-1191.

[5] Y.K. Sun, S.T. Myung, B.C. Park, J. Prakash, I. Belharouak, K. Amine, High-energy cathode 
material for long-life and safe lithium batteries, Nat. Mater. 8 (2009) 320-324.

[6] D. Wang, X. Li, Z. Wang, H. Guo, X. Chen, X. Zheng, Y. Xu, J. Ru, Multifunctional $\mathrm{Li}_{2} \mathrm{O}-2 \mathrm{~B}_{2} \mathrm{O}_{3}$ coating for enhancing high voltage electrochemical performances and thermal stability of layered structured $\mathrm{LiNi}_{0.5} \mathrm{Co}_{0.2} \mathrm{Mn}_{0.3} \mathrm{O}_{2}$ cathode materials for lithium ion batteries, Electrochim. Acta 174 (2015) 1225-1233.

[7] J. Lu, Q. Peng, W.Y. Wang, C.Y. Nan, L.H. Li, Y.D. Li, Nanoscale Coating of $\mathrm{LiMO}_{2}(\mathrm{M}=\mathrm{Ni}$, Co, Mn) Nanobelts with $\mathrm{Li}^{+}$-Conductive $\mathrm{Li}_{2} \mathrm{TiO}_{3}$ : Toward Better Rate Capabilities for Li-Ion Batteries, J. Am. Chem. Soc. 135 (2013) 1649-1652.

[8] C. Wang, F. Zhou, K. Chen, J. Kong, Y. Jiang, G. Yan, J. Li, C. Yu, W.-P. Tang, Electrochemical properties of alpha- $\mathrm{MoO}_{3}$-coated $\mathrm{Li}\left(\mathrm{Li}_{0.2} \mathrm{Mn}_{0.54} \mathrm{Ni}_{0.13} \mathrm{Co}_{0.13}\right) \mathrm{O}_{2}$ cathode material for Li-ion batteries, Electrochim. Acta 176 (2015) 1171-1181.

[9] W.S. Yoon, C.P. Grey, M. Balasubramanian, X.Q. Yang, J. McBreen, In situ X-ray absorption spectroscopic study on $\mathrm{LiNi}_{0.5} \mathrm{Mn}_{0.5} \mathrm{O}_{2}$ cathode material during electrochemical cycling, Chem. Mater. 15 (2003) 3161-3169.

[10] X. Yang, Z. Zuo, H. Wang, Q. Chen, H. Zhang, Z. Huang, B. Wu, H. Zhou, The Contradiction Between the Half-Cell and Full-Battery Evaluations on the Tungsten-Coating $\operatorname{LiNi}_{0.5} \mathrm{Co}_{0.2} \mathrm{Mn}_{0.3} \mathrm{O}_{2}$ Cathode, Electrochim. Acta 180 (2015) 604-609.

[11] X. Yang, R. Yu, L. Ge, D. Wang, Q. Zhao, X. Wang, Y. Bai, H. Yuan, H. Shu, Facile synthesis and performances of nanosized $\mathrm{Li}_{2} \mathrm{TiO}_{3}$-based shell encapsulated $\mathrm{LiMn}_{1 / 3} \mathrm{Ni}_{1 / 3} \mathrm{Co}_{1 / 3} \mathrm{O}_{2}$ microspheres, J. Mater. Chem. A 2 (2014) 8362-8368.

[12] J. Cho, Y.J. Kim, T.J. Kim, B. Park, Zero-strain intercalation cathode for rechargeable Li-ion cell, Angew. Chem. Int. Ed. 40 (2001) 3367-3369. 
[13] J. Cho, Y.W. Kim, B. Kim, J.G. Lee, B. Park, A breakthrough in the safety of lithium secondary batteries by coating the cathode material with $\mathrm{AIPO}_{4}$ nanoparticles, Angew. Chem. Int. Ed. 42 (2003) 1618-1621.

[14] J. Du, Z. Zhang, J. Peng, Y. Han, Y. Xia, S. Ju, S. Guo, C. Leng, G. Chen, L. Xu, J. Sun, H. Yan, Effects of $\mathrm{ZrO}_{2}$ Coating on $\mathrm{LiNi}_{1 / 3} \mathrm{Mn}_{1 / 3} \mathrm{Co}_{1 / 3} \mathrm{O}_{2}$ Particle with Microwave Pyrolysis, J. Mater. Eng. Perform. 23 (2014) 2159-2163.

[15] J. Du, Z. Zhang, J. Peng, Y. Han, Y. Xia, S. Guo, S. Ju, C. Leng, G. Chen, L. Xu, J. Sun, H. Yan, Improvement of electrochemical properties of $\mathrm{LiNi}_{1 / 3} \mathrm{Mn}_{1 / 3} \mathrm{Co}_{1 / 3} \mathrm{O}_{2}$ by coating with $\mathrm{La}_{0.4} \mathrm{Ca}_{0.6} \mathrm{CoO}_{3}$, J. Solid State Electr. 18 (2014) 2211-2216.

[16] H. Lin, J. Zheng, Y. Yang, The effects of quenching treatment and $\mathrm{AlF}_{3}$ coating on $\mathrm{LiNi}_{0.5} \mathrm{Mn}_{0.5} \mathrm{O}_{2}$ cathode materials for lithium-ion battery, Mater. Chem. Phys. 119 (2010) 519-523.

[17] S.U. Woo, C.S. Yoon, K. Amine, I. Belharouak, Y.K. Sun, Significant improvement of electrochemical performance of $\mathrm{AlF}_{3}$-coated $\mathrm{LiNi}_{0.8} \mathrm{Co}_{0.1} \mathrm{Mn}_{0.1} \mathrm{O}_{2}$ cathode materials, J. Electrochem. Soc. 154 (2007) A1005-A1009.

[18] K. Araki, N. Taguchi, H. Sakaebe, K. Tatsumi, Z. Ogumi, Electrochemical properties of $\mathrm{LiNi}_{1 / 3} \mathrm{Co}_{1 / 3} \mathrm{Mn}_{1 / 3} \mathrm{O}_{2}$ cathode material modified by coating with $\mathrm{Al}_{2} \mathrm{O}_{3}$ nanoparticles, J. Power Sources 269 (2014) 236-243.

[19] J.H. Park, J.H. Cho, S.B. Kim, W.S. Kim, S.Y. Lee, S.Y. Lee, A novel ion-conductive protection skin based on polyimide gel polymer electrolyte: application to nanoscale coating layer of high voltage $\mathrm{LiNi}_{1 / 3} \mathrm{Co}_{1 / 3} \mathrm{Mn}_{1 / 3} \mathrm{O}_{2}$ cathode materials for lithium-ion batteries, J. Mater. Chem. 22 (2012) 12574-12581.

[20] E. Zhao, X. Liu, Z. Hu, L. Sun, X. Xiao, Facile synthesis and enhanced electrochemical 
performances of $\mathrm{Li}_{2} \mathrm{TiO}_{3}$-coated lithium-rich layered $\mathrm{Li}_{1.13} \mathrm{Ni}_{0.30} \mathrm{Mn}_{0.57} \mathrm{O}_{2}$ cathode materials for lithium-ion batteries, J. Power Sources 294 (2015) 141-149.

[21] H. Deng, P. Nie, H. Luo, Y. Zhang, J. Wang, X. Zhang, Highly enhanced lithium storage capability of $\mathrm{LiNi}_{0.5} \mathrm{Mn}_{1.5} \mathrm{O}_{4}$ by coating with $\mathrm{Li}_{2} \mathrm{TiO}_{3}$ for Li-ion batteries, J. Mater. Chem. A 2 (2014) 18256-18262.

[22] X. Yi, X. Wang, B. Ju, H. Shu, W. Wen, R. Yu, D. Wang, X. Yang, Effective enhancement of electrochemical performance for spherical spinel $\mathrm{LiMn}_{2} \mathrm{O}_{4}$ via $\mathrm{Li}$ ion conductive $\mathrm{Li}_{2} \mathrm{ZrO}_{3}$ coating, Electrochim. Acta 134 (2014) 143-149.

[23] X. Zhang, S. Sun, Q. Wu, N. Wan, D. Pan, Y. Bai, Improved electrochemical and thermal performances of layered $\mathrm{Li}\left(\mathrm{Li}_{0.2} \mathrm{Ni}_{0.17} \mathrm{Co}_{0.07} \mathrm{Mn}_{0.56}\right) \mathrm{O}_{2}$ via $\mathrm{Li}_{2} \mathrm{ZrO}_{3}$ surface modification, J. Power Sources 282 (2015) 378-384.

[24] X. Miao, H. Ni, H. Zhang, C. Wang, J. Fang, G. Yang, $\mathrm{Li}_{2} \mathrm{ZrO}_{3}$-coated $0.4 \mathrm{Li}_{2} \mathrm{MnO}_{3}$ center dot $0.6 \mathrm{LiNi}_{1 / 3} \mathrm{Co}_{1 / 3} \mathrm{Mn}_{1 / 3} \mathrm{O}_{2}$ for high performance cathode material in lithium-ion battery, J. Power Sources 264 (2014) 147-154.

[25] E.Y. Zhao, M.M. Chen, D.F. Chen, X.L. Xiao, Z.B. Hu, A Versatile Coating Strategy to Highly Improve the Electrochemical Properties of Layered Oxide $\mathrm{LiMO}_{2}\left(\mathrm{M}=\mathrm{Ni}_{0.5} \mathrm{Mn}_{0.5}\right.$ and $\left.\mathrm{Ni}_{1 / 3} \mathrm{Mn}_{1 / 3} \mathrm{Co}_{1 / 3}\right)$, ACS Appl. Mater. Interfaces 7 (2015) 27096-27105.

[26] E. Zhao, X. Liu, H. Zhao, X. Xiao, Z. Hu, Ion conducting $\mathrm{Li}_{2} \mathrm{SiO}_{3}$-coated lithium-rich layered oxide exhibiting high rate capability and low polarization, Chem. Commun. 51 (2015) 9093-9096. [27] K. Nakamura, H. Hirano, Y. Michihiro, T. Moriga, Changes in the local structure and $\mathrm{Li}^{+}$ion dynamics in lithium manganese oxides prepared by mechanical milling, Solid State Ionics 181 (2010) 1359-1365. 
[28] N. Yabuuchi, K. Yoshii, S.T. Myung, I. Nakai, S. Komaba, Detailed Studies of a High-Capacity Electrode Material for Rechargeable Batteries, $\mathrm{Li}_{2} \mathrm{MnO}_{3}-\mathrm{LiCo}_{1 / 3} \mathrm{Ni}_{1 / 3} \mathrm{Mn}_{1 / 3} \mathrm{O}_{2}, \mathrm{~J}$. Am. Chem. Soc. 133 (2011) 4404-4419.

[29] C.S. Johnson, N.C. Li, C. Lefief, J.T. Vaughey, M.M. Thackeray, Synthesis, Characterization and Electrochemistry of Lithium Battery Electrodes: $\mathrm{xLi}_{2} \mathrm{MnO}_{3}$ center dot (1-x)LiMn ${ }_{0.333} \mathrm{Ni}_{0.333} \mathrm{Co}_{0.333} \mathrm{O}_{2}(0<=\mathrm{x}<=0.7)$, Chem. Mater. 20 (2008) 6095-6106.

[30] Y.K. Sun, S.T. Myung, B.C. Park, K. Amine, Synthesis of spherical nano- to microscale core-shell particles $\mathrm{Li}\left(\mathrm{Ni}_{0.8} \mathrm{Co}_{0.1} \mathrm{Mn}_{0.1}\right)_{1-\mathrm{x}}\left(\mathrm{Ni}_{0.5} \mathrm{Mn}_{0.5}\right)_{\mathrm{x}} \mathrm{O}_{2}$ and their applications to lithium batteries, Chem. Mater. 18 (2006) 5159-5163.

[31] Y.K. Sun, S.T. Myung, H.S. Shin, Y.C. Bae, C.S. Yoon, Novel core-shell-structured Li $\left(\mathrm{Ni}_{0.8} \mathrm{Co}_{0.2}\right)_{0.8}\left(\mathrm{Ni}_{0.5} \mathrm{Mn}_{0.5}\right)_{0.2} \mathrm{O}_{2}$ via coprecipitation as positive electrode material for lithium secondary batteries, J. Phys. Chem. B 110 (2006) 6810-6815.

[32] T. Ohzuku, Y. Makimura, Layered lithium insertion material of $\mathrm{LiNi}_{1 / 2} \mathrm{Mn}_{1 / 2} \mathrm{O}_{2}$ : A possible alternative to $\mathrm{LiCoO}_{2}$ for advanced lithium-ion batteries, Chem. Lett. (2001) 744-745.

[33] C. Li, H.P. Zhang, L.J. Fu, H. Liu, Y.P. Wu, E. Ram, R. Holze, H.Q. Wu, Cathode materials modified by surface coating for lithium ion batteries, Electrochim. Acta 51 (2006) 3872-3883.

[34] L.J. Fu, H. Liu, C. Li, Y.P. Wu, E. Rahm, R. Holze, H.Q. Wu, Surface modifications of electrode materials for lithium ion batteries, Solid State Sci. 8 (2006) 113-128.

[35] J.Q. Zhao, Y. Wang, Ultrathin Surface Coatings for Improved Electrochemical Performance of Lithium Ion Battery Electrodes at Elevated Temperature, J. Phys. Chem. C 116 (2012) 11867-11876.

[36] M.W. Pitcher, Y.N. He, P.A. Bianconi, Facile in situ synthesis of oriented $\mathrm{LiNbO}_{3}$ single 
crystals in a polymer matrix, Mater. Chem. Phys. 90 (2005) 57-61.

[37] S. Lim, J. Cho, PVP-Assisted $\mathrm{ZrO}_{2}$ coating on $\mathrm{LiMn}_{2} \mathrm{O}_{4}$ spinel cathode nanoparticles prepared by $\mathrm{MnO}_{2}$ nanowire templates, Electrochem. Commun. 10 (2008) 1478-1481.

[38] Y. Cho, S. Lee, Y. Lee, T. Hong, J. Cho, Spinel-Layered Core-Shell Cathode Materials for Li-Ion Batteries, Adv. Energy Mater. 1 (2011) 821-828.

[39] G.E. Muilenberg, C.D. Wagner, Handbook of x-ray photoelectron spectroscopy: a reference book of standard data for use in x-ray photoelectron spectroscopy, Perkin-Elmer Corp., Physical Electronics Division, Eden Prairie, Minn, 1979.

[40] F. Lian, P. Axmann, C. Stinner, Q.G. Liu, M. Wohlfahrt-Mehrens, Comparative study of the preparation and electrochemical performance of $\mathrm{LiNi}_{1 / 2} \mathrm{Mn}_{1 / 2} \mathrm{O}_{2}$ electrode material for rechargeable lithium batteries, J. Appl. Electrochem. 38 (2008) 613-617.

[41] L. Li, Q. Yao, Z. Chen, L. Song, T. Xie, H. Zhu, J. Duan, K. Zhang, Effects of lithium-active manganese trioxide coating on the structural and electrochemical characteristics of $\mathrm{LiNi}_{0.5} \mathrm{Co}_{0.2} \mathrm{Mn}_{0.3} \mathrm{O}_{2}$ as cathode materials for lithium ion battery, J. Alloy. Compound. 650 (2015) 684-691.

[42] A. Boulineau, L. Croguennec, C. Delmas, F. Weill, Reinvestigation of $\mathrm{Li}_{2} \mathrm{MnO}_{3}$ Structure: Electron Diffraction and High Resolution TEM, Chem. Mater. 21 (2009) 4216-4222.

[43] B. Philippe, R. Dedryvere, J. Allouche, F. Lindgren, M. Gorgoi, H. Rensmo, D. Gonbeau, K. Edstrom, Nanosilicon Electrodes for Lithium-Ion Batteries: Interfacial Mechanisms Studied by Hard and Soft X-ray Photoelectron Spectroscopy, Chem. Mater. 24 (2012) 1107-1115.

[44] Q. Li, G. Li, C. Fu, D. Luo, J. Fan, L. Li, K'-Doped $\mathrm{Li}_{1.2} \mathrm{Mn}_{0.54} \mathrm{Co}_{0.13} \mathrm{Ni}_{0.13} \mathrm{O}_{2}$ : A Novel Cathode Material with an Enhanced Cycling Stability for Lithium-Ion Batteries, Acs Appl. Mater. Inter. 6 (2014) 10330-10341. 
[45] D. Qian, B. Xu, H.-M. Cho, T. Hatsukade, K.J. Carroll, Y.S. Meng, Lithium Lanthanum Titanium Oxides: A Fast Ionic Conductive Coating for Lithium-Ion Battery Cathodes, Chem. Mater. 24 (2012) 2744-2751.

[46] J. Xie, N. Imanishi, T. Matsumura, A. Hirano, Y. Takeda, O. Yamamoto, Orientation dependence of Li-ion diffusion kinetics in $\mathrm{LiCoO}_{2}$ thin films prepared by RF magnetron sputtering, Solid State Ionics 179 (2008) 362-370.

[47] S. Lee, M. Jeong, J. Cho, Optimized 4 V Spinel Cathode Material with High Energy Density for Li-Ion Cells Operating at 60 degrees C, Adv. Energy Mater. 3 (2013) 1623-1629.

\section{Figure captions}

Figure 1. (a) Schematic illustration of the preparation process for the $\mathrm{Li}_{2} \mathrm{MnO}_{3}$ coated $\mathrm{LiNi}_{0.8} \mathrm{Mn}_{0.1} \mathrm{Co}_{0.1} \mathrm{O}_{2}$; (b) The structure of $\mathrm{Li}_{2} \mathrm{MnO}_{3}$, distribution of $\mathrm{Li}^{+}$along a-b plane and c axis;

(c) Details of the interface between the $\mathrm{Li}_{2} \mathrm{MnO}_{3}$ surface layer and the $\mathrm{LiMO}_{2}$ host material.

Figure 2. X-ray photoelectron spectroscopy (XPS) spectra of: (a) Ni 2 $\mathrm{p}_{3 / 2}$, (b) $\mathrm{Mn} 2 \mathrm{p}_{3 / 2}$ and (c) Co $2 \mathrm{p}_{3 / 2}$ for the hydroxyl precursor $\mathrm{Ni}_{0.8} \mathrm{Mn}_{0.1} \mathrm{Co}_{0.1}(\mathrm{OH})_{2}$.

Figure 3. (a) The XRD pattern for the pristine and $\mathrm{Li}_{2} \mathrm{MnO}_{3}$ coated $\mathrm{LiNi}_{0.8} \mathrm{Mn}_{0.1} \mathrm{Co}_{0.1} \mathrm{O}_{2}$ electrodes; (b) The XRD pattern for the $\mathrm{Li}_{2} \mathrm{MnO}_{3}$ coated $\mathrm{LiMO}_{2}$ with a Mn:M ratio of 50:100 in mole.

Figure 4. Scanning electron micrographs for (a, b) pristine $\mathrm{LiNi}_{0.8} \mathrm{Mn}_{0.1} \mathrm{Co}_{0.1} \mathrm{O}_{2}$ and (c, d) $\mathrm{Li}_{2} \mathrm{MnO}_{3}$ coated $\mathrm{LiNi}_{0.8} \mathrm{Mn}_{0.1} \mathrm{Co}_{0.1} \mathrm{O}_{2}$ in various magnification.

Figure 5. (a) TEM images of the $\mathrm{Li}_{2} \mathrm{MnO}_{3}$ coated $\mathrm{LiNi}_{0.8} \mathrm{Mn}_{0.1} \mathrm{Co}_{0.1} \mathrm{O}_{2}$ and the inset shows the lattice fringes of the inner material and the external coating layer; (b) High-angle annular dark-field scanning TEM (HAADF-STEM) of the $\mathrm{Li}_{2} \mathrm{MnO}_{3}$ coated $\mathrm{LiNi}_{0.8} \mathrm{Mn}_{0.1} \mathrm{Co}_{0.1} \mathrm{O}_{2}$ sample and elemental mapping results of (c) $\mathrm{Ni}$, (d) $\mathrm{Mn}$ and (e) Co; X-ray photoelectron spectroscopy 
(XPS) spectra of: f) $\mathrm{Ni} 2 \mathrm{p}_{3 / 2}$, (g) $\mathrm{Mn} 2 \mathrm{p}_{3 / 2}$ and (h) $\mathrm{Co} 2 \mathrm{p}_{3 / 2}$ for the $\mathrm{Li}_{2} \mathrm{MnO}_{3}$ coated $\mathrm{LiNi}_{0.8} \mathrm{Mn}_{0.1} \mathrm{Co}_{0.1} \mathrm{O}_{2}$ sample.

Figure 6. (a) Plots of specific discharge capacity vs. cycle number for the pristine and $\mathrm{Li}_{2} \mathrm{MnO}_{3}$ coated electrodes; (b) Specific capacity vs. voltage curves for the pristine and $\mathrm{Li}_{2} \mathrm{MnO}_{3}$ coated electrodes at the $150^{\text {th }}$ cycle. $\mathrm{dQ} / \mathrm{dV}$ profiles for (c) the pristine $\mathrm{LiNi}_{0.8} \mathrm{Mn}_{0.1} \mathrm{Co}_{0.1} \mathrm{O}_{2}$ and (d) the $\mathrm{Li}_{2} \mathrm{MnO}_{3}$ coated electrode calculated from numerical data observed after $1^{\text {st }}, 30^{\text {th }}, 60^{\text {th }}, 100^{\text {th }}$ and $150^{\text {th }}$ cycle at $1 \mathrm{C}$, insets show the variation trend of discharge voltage after different cycles. (e) The rate performances of the pristine and $\mathrm{Li}_{2} \mathrm{MnO}_{3}$ coated electrodes.

Figure 7. PITT curves for the (a) pristine $\mathrm{LiNi}_{0.8} \mathrm{Mn}_{0.1} \mathrm{Co}_{0.1} \mathrm{O}_{2}$ and (b) $\mathrm{Li}_{2} \mathrm{MnO}_{3}$ coated electrode. Lithium diffusion coefficients $\left(\mathrm{D}_{\mathrm{Li}}\right)$ as a function of the voltage during (c) charge and (d) discharge processes between 3.0 and $4.3 \mathrm{~V}$. 
a)

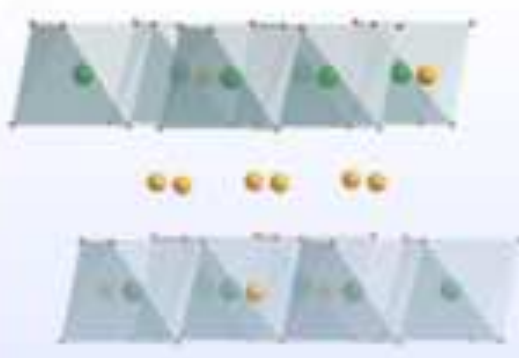

\section{Distribution of $\mathrm{Li}^{+}$} along $\mathrm{a}-\mathrm{b}$ plane

b)

\section{e $\mathrm{Li}^{+}$ \\ - $\mathrm{Mn}^{4+}$ \\ - $\mathrm{O}^{2-}$}

PVP-coated

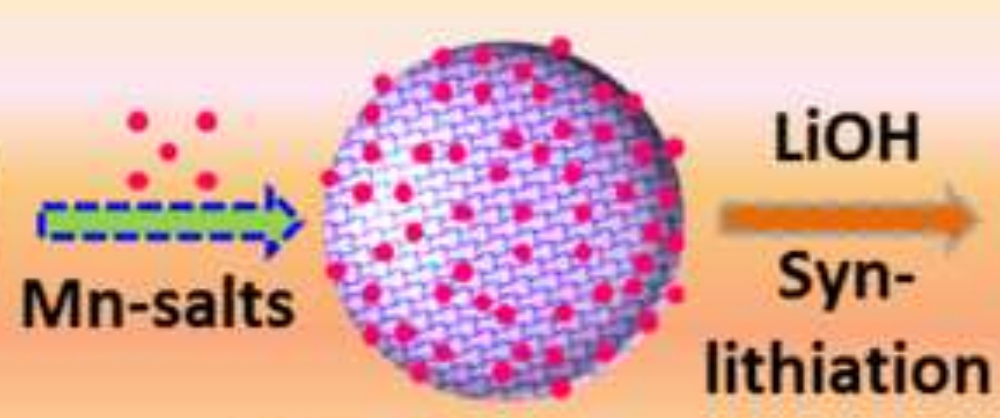

PVP-Mn-coated

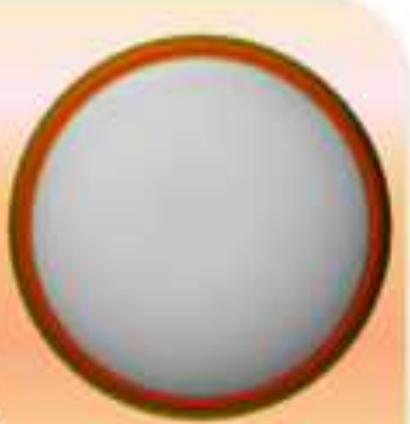

$\mathrm{Li}_{2} \mathrm{MnO}_{3}$-coated

c)

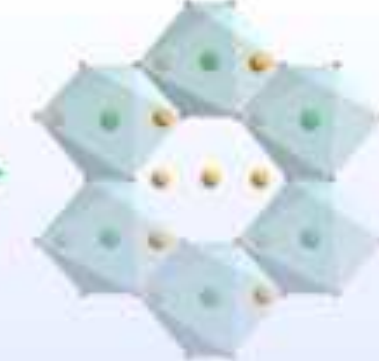

Distribution of $\mathrm{Li}^{+}$ along $\mathrm{c}$ axis
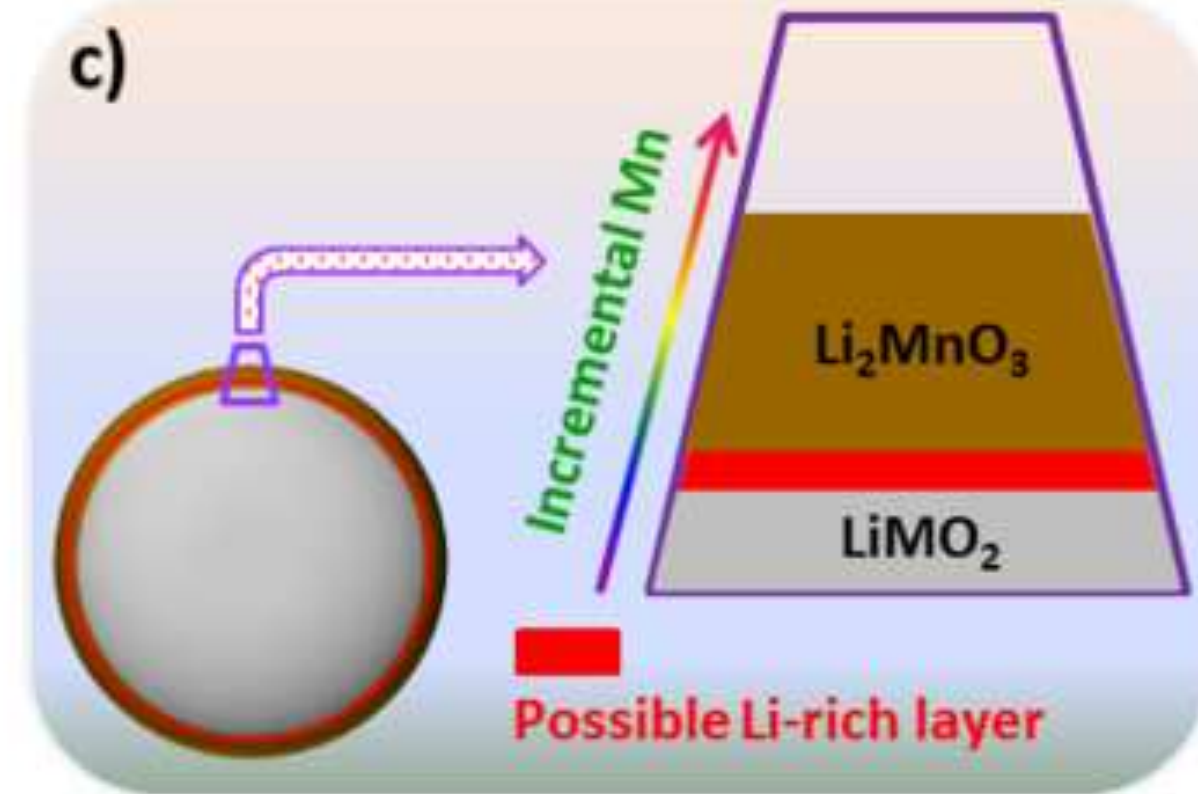

Possible Li-rich layer 

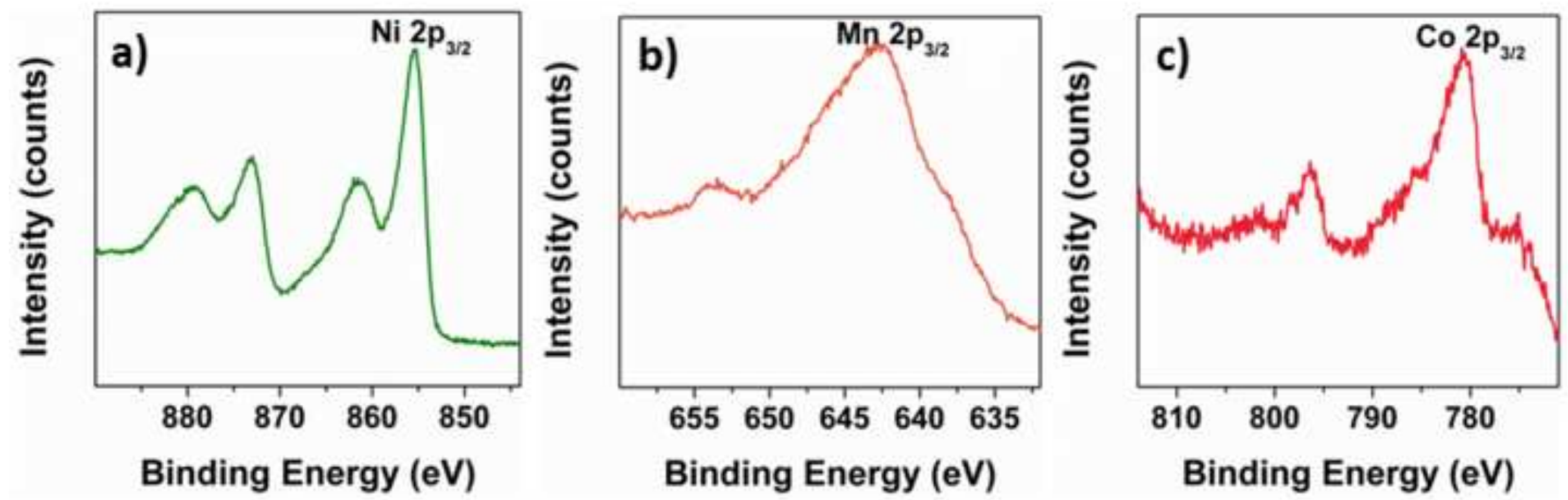

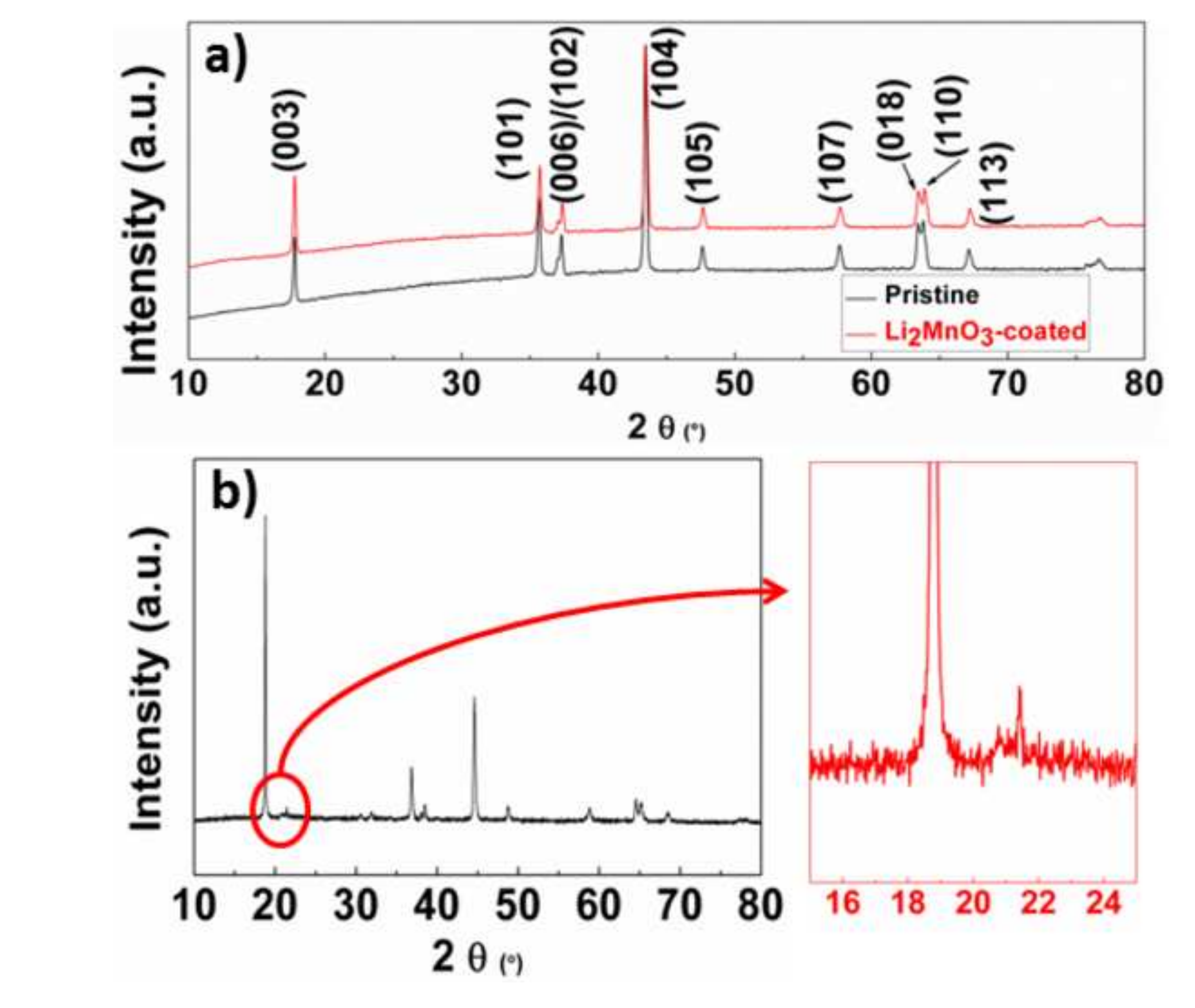

$$
\text { . }
$$

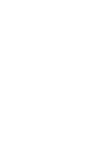

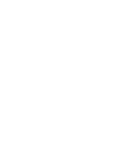




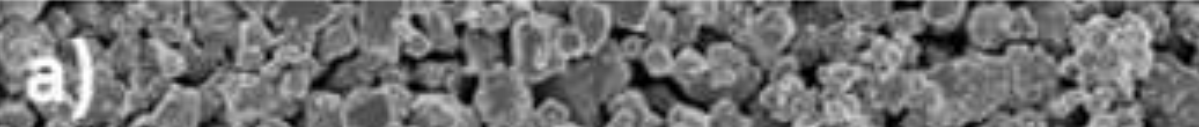
L. t.

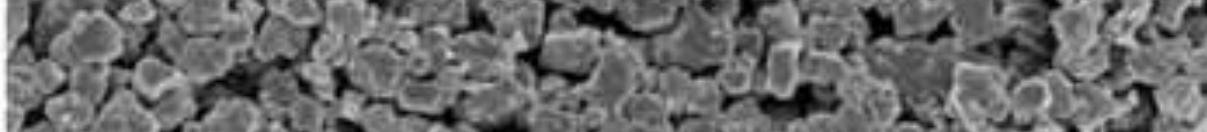

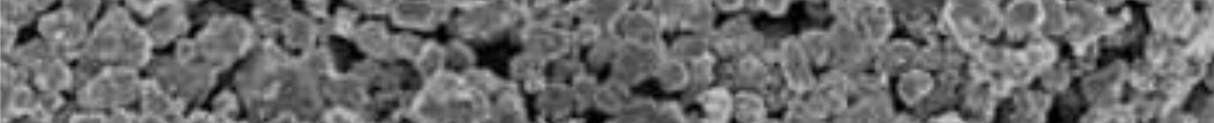

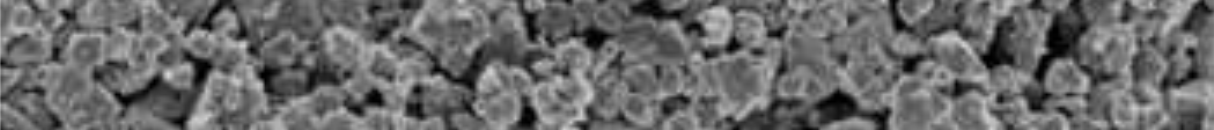

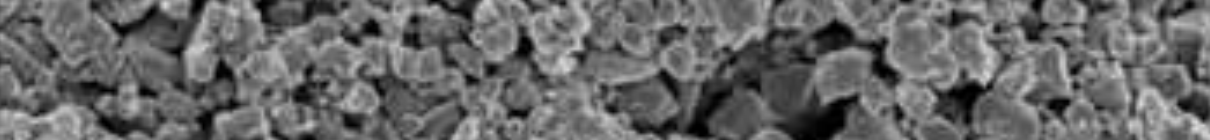

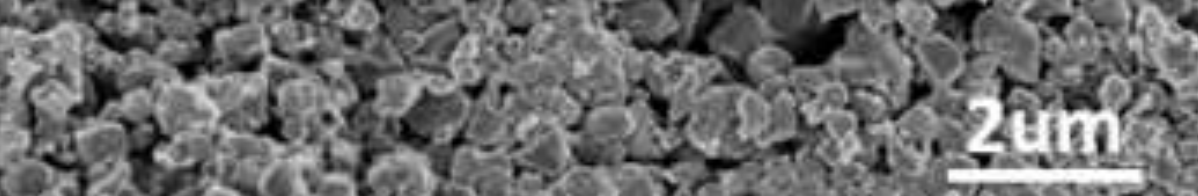

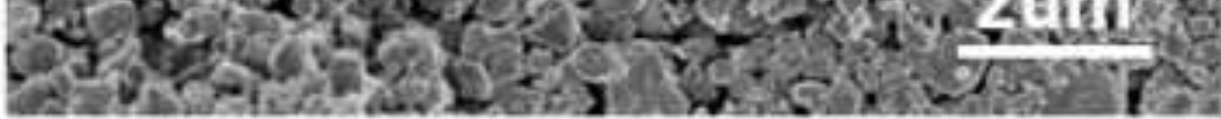
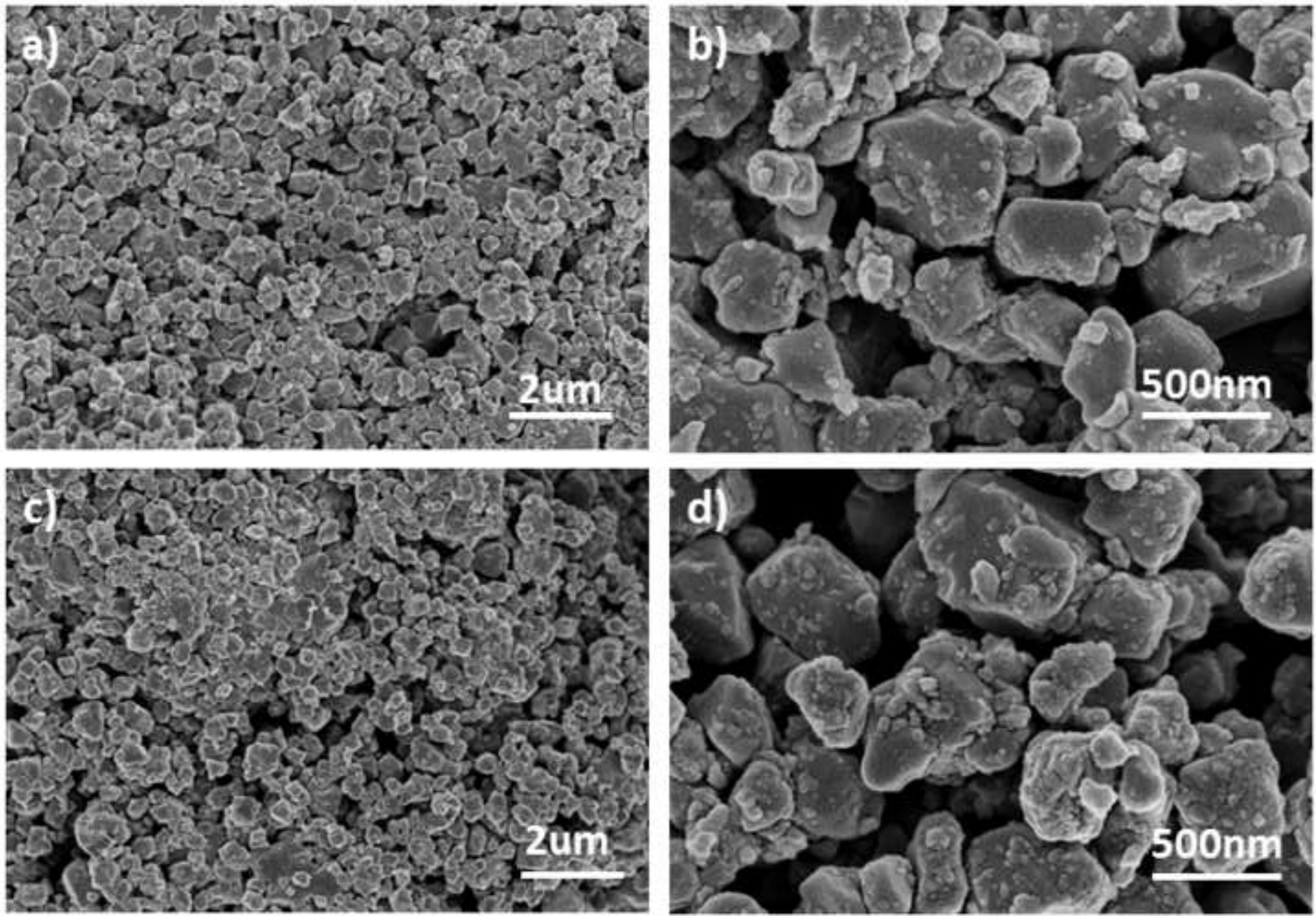

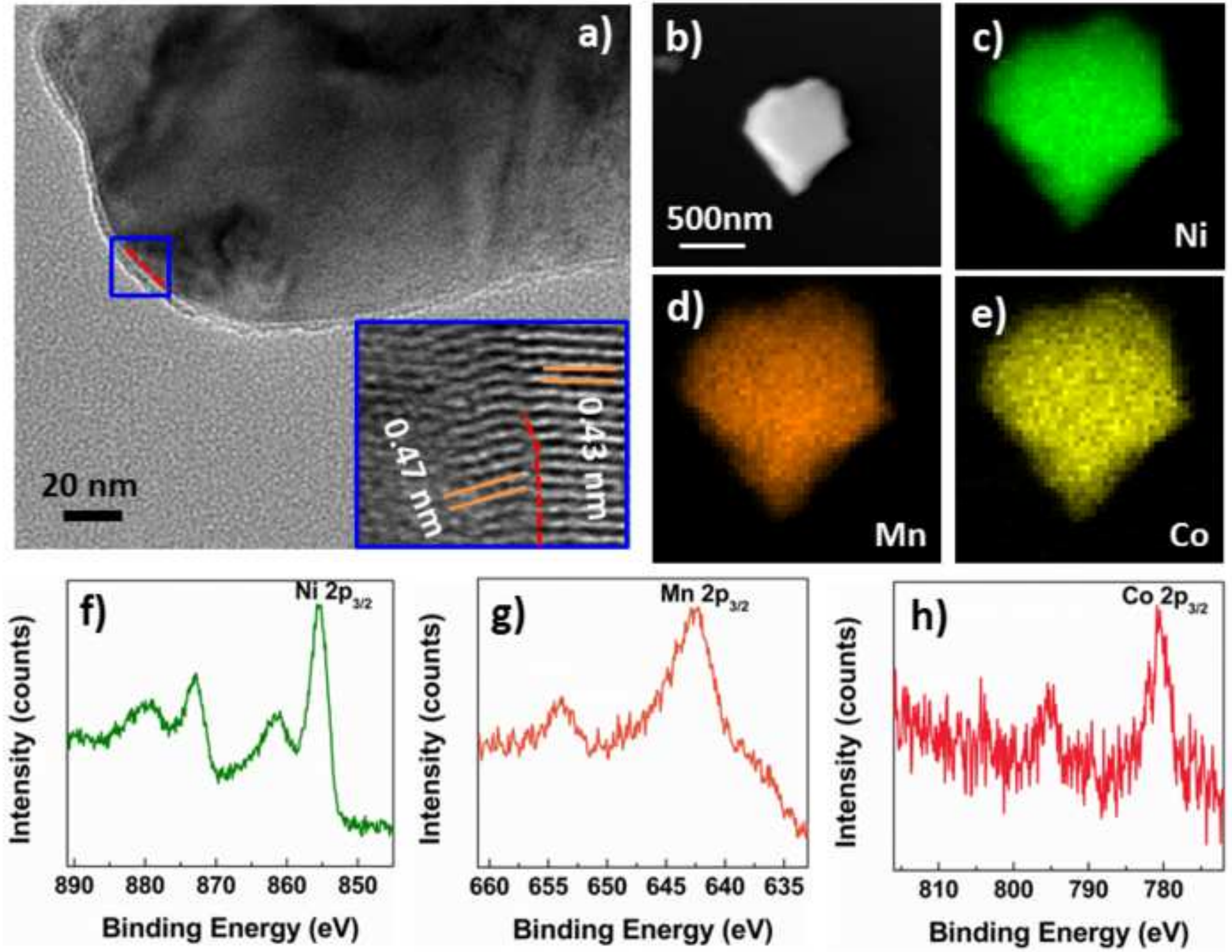

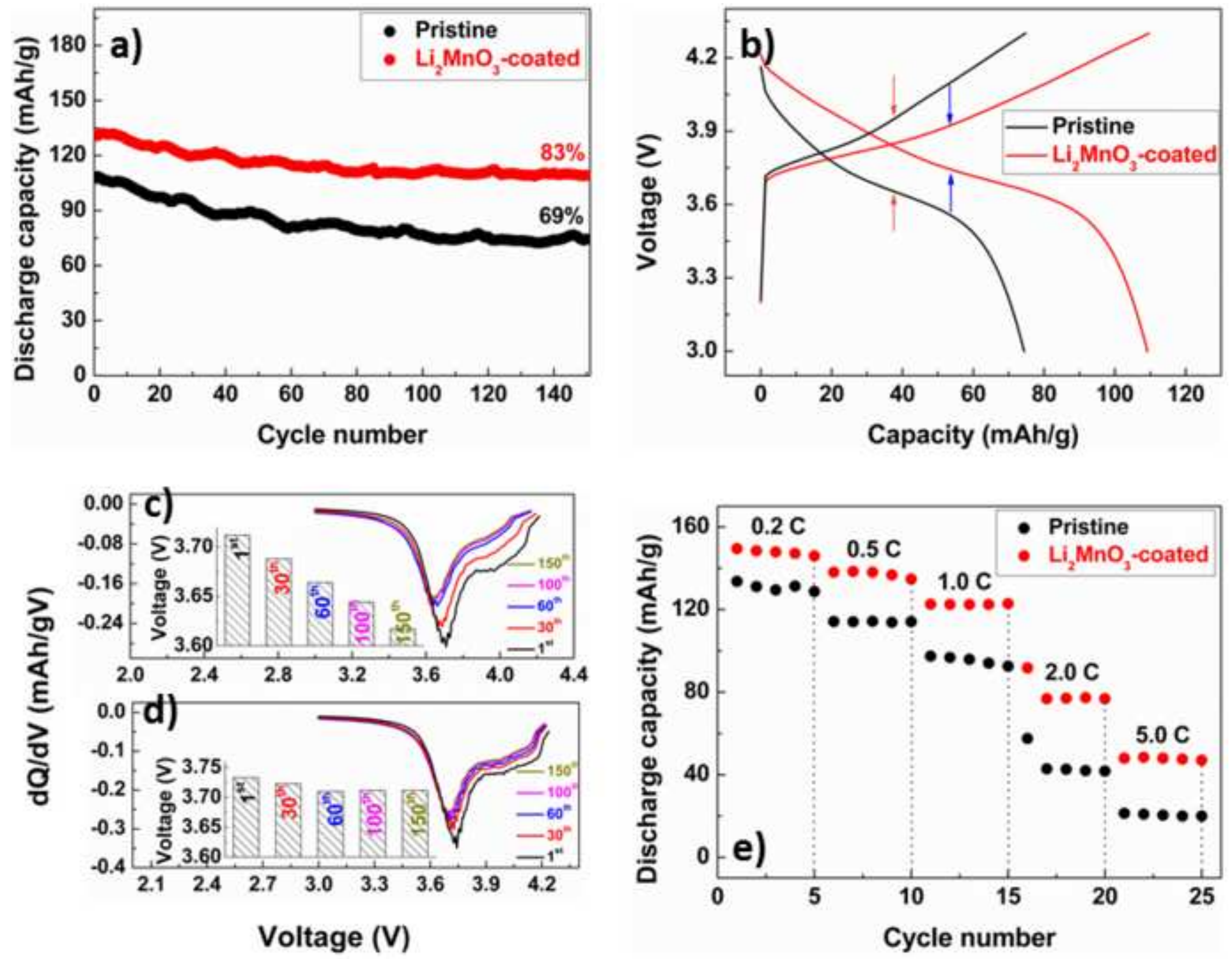

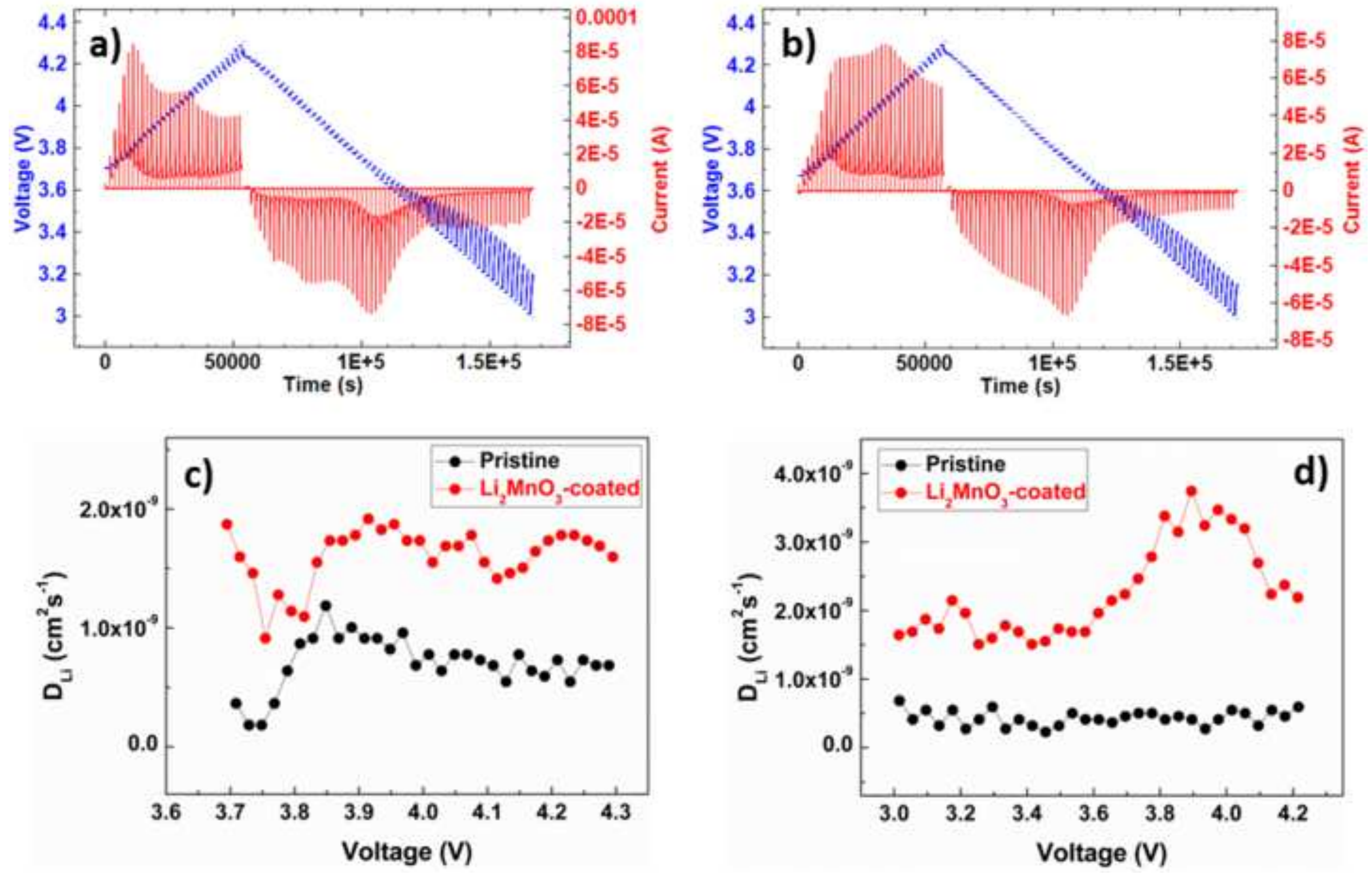
Table 1.

ICP results (molar percentage content) of the pristine and $\mathrm{Li}_{2} \mathrm{MnO}_{3}$ coated $\mathrm{LiNi}_{0.8} \mathrm{Mn}_{0.1} \mathrm{Co}_{0.1} \mathrm{O}_{2}$ samples

\begin{tabular}{ccccc}
\hline & $\mathrm{Li}$ & $\mathrm{Ni}$ & $\mathrm{Mn}$ & $\mathrm{Co}$ \\
\hline $\mathrm{LiNi}_{0.8} \mathrm{Mn}_{0.1} \mathrm{Co}_{0.1} \mathrm{O}_{2}$ & $1.05 \%$ & $0.83 \%$ & $0.09 \%$ & $0.10 \%$ \\
\hline $\mathrm{LiNi}_{0.8} \mathrm{Mn}_{0.1} \mathrm{Co}_{0.1} \mathrm{O}_{2} @ \mathrm{Li}_{2} \mathrm{MnO}_{3}$ & $1.12 \%$ & $0.72 \%$ & $0.19 \%$ & $0.09 \%$ \\
\hline
\end{tabular}


Table 2 .

Atomic ratios of $\mathrm{Mn}:(\mathrm{Ni}+\mathrm{Co})$ of the $\mathrm{Li}_{2} \mathrm{MnO}_{3}$ coated $\mathrm{LiNi}_{0.8} \mathrm{Mn}_{0.1} \mathrm{Co}_{0.1} \mathrm{O}_{2}$ which are obtained from XPS and the precursor, respectively.

\begin{tabular}{ccc}
\hline & XPS & starting ratio \\
\hline $\mathrm{Mn}:(\mathrm{Ni}+\mathrm{Co})$ & $3.56:(5.14+0.48)$ & $2:(8+1)$ \\
\hline
\end{tabular}



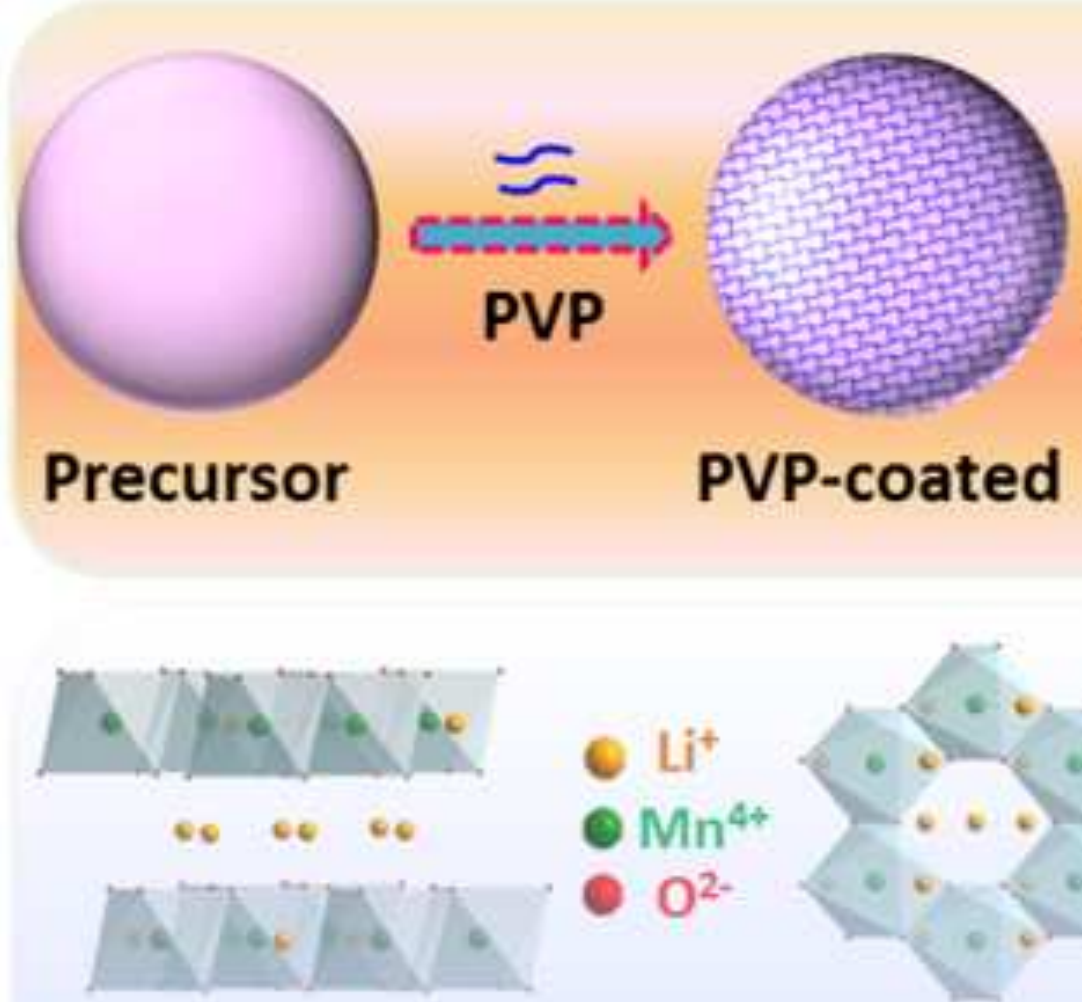

Distribution of $\mathrm{Li}^{+}$ along $\mathrm{a}-\mathrm{b}$ plane

\section{e $\mathrm{Li}^{+}$ \\ - $\mathrm{Mn}^{4+}$ \\ - $\mathrm{O}^{2-}$}

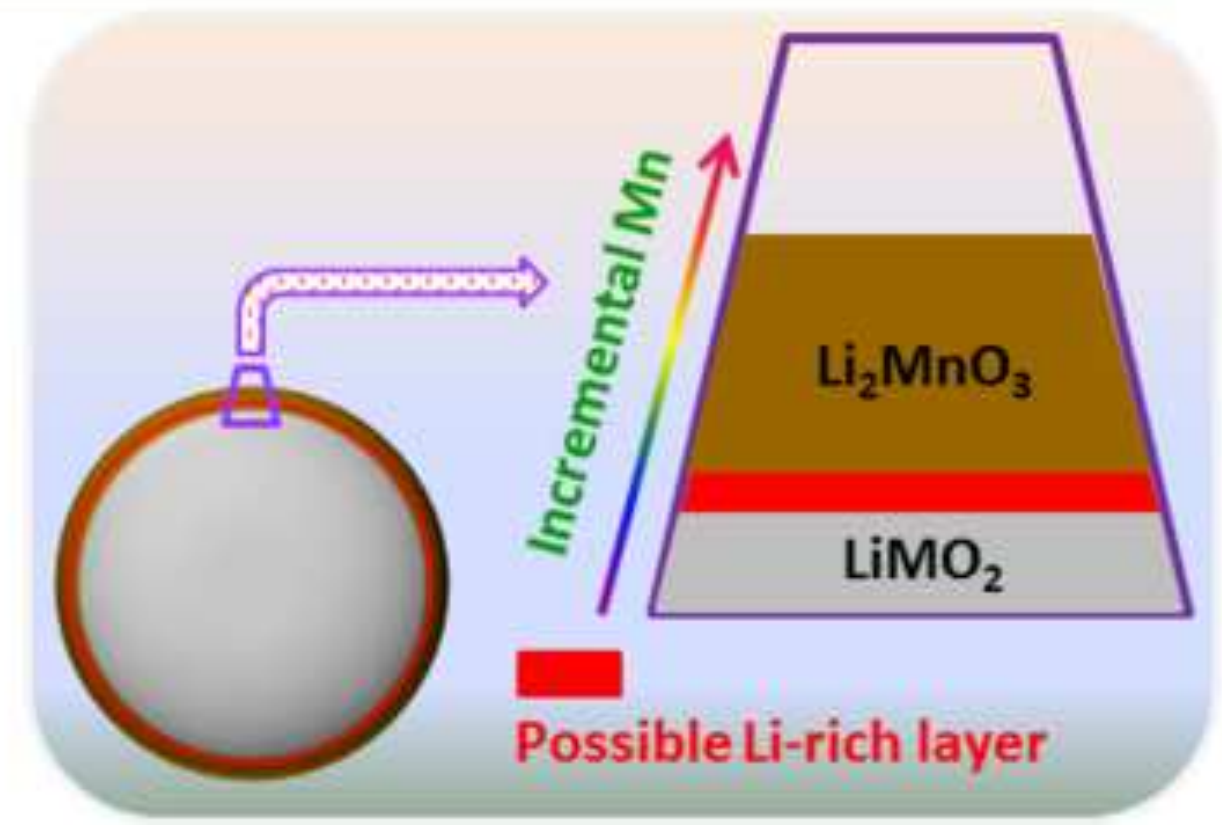

Mn-salts

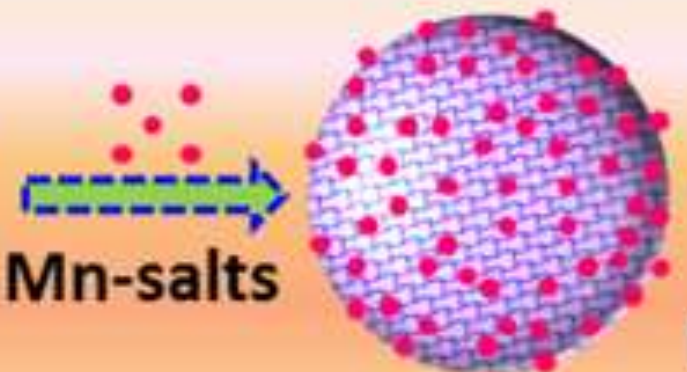

\section{LiOH}

Synlithiation

PVP-Mn-coated $\mathrm{Li}_{2} \mathrm{MnO}_{3}$-coated along $\mathrm{c}$ axis
Distribution of $\mathrm{Li}^{+}$

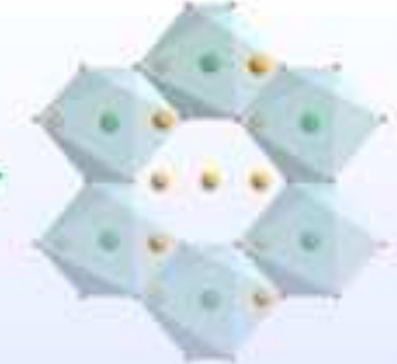

